\title{
Does Better Physical Function Make People Happier?
}

\author{
Imam Budidharma $^{1} \&$ Heni Wahyuni ${ }^{2}$ \\ ${ }^{1}$ Board of Regional Development Planning of the Special Province of Yogyakarta, Indonesia \\ ${ }^{2}$ Faculty of Economics and Business, Universitas Gadjah Mada, Yogyakarta, Indonesia \\ Correspondence: Heni Wahyuni, Faculty of Economics and Business, Universitas Gadjah Mada, Jl. Sosio \\ Humanora No. 1, Bulaksumur, Yogyakarta, Indonesia 55281. E-mail: hwahyuni@ugm.ac.id
}

Received: December 12, 2016

doi:10.5539/ass.v13n3p58
Accepted: January 10, 2017 Online Published: February 15, 2017

URL: http://dx.doi.org/10.5539/ass.v13n3p58

\begin{abstract}
The objective of this paper is analyzing the impact of health status on the subjective well-being. The study uses the recent data from Indonesian Family Life Survey and the physical function index as a proxy for health status. Ordered Logit regression is performed to estimate the impact of the physical function on the subjective well-being. The study employs an instrumental variable approach to address the endogeneity issue of the physical function. After controlling for socioeconomic and demographic factors, it is found that the physical function has a positive effect on the subjective well-being. On average, an increase in 1 percent of an individual physical function will increase a probability of being very happy by 1.5 percent. However, this impact is decreased after including mental health on the regression model. Since the magnitude of the coefficient in IV-Ordered Logit is larger than in ordinary Ordered Logit, we interpret that there is no existence of a reversed causality. Then, it can be concluded that the physical function is a predictor for the subjective well-being.
\end{abstract}

Keywords: subjective well-being, health, physical function, ordered logit, instrumental variable

\section{Introduction}

Health is one of the most important aspects of human capital that is related to individual's welfare. Grossman (1972) argues that individual's stock of health determines the total amount of time individual can spend producing money earnings and commodities. Further, Bloom and Canning (2000) explain four pathways through which health affect economic prosperity. First, healthier people may be more productive since they have fewer lost workdays caused by illness. Second, healthier people have more opportunity to invest in education and receive greater return from this investment. Third, improvement in longevity induces people to save more for retirement. Finally, improvement of health condition will shape the demographic structure. The low rate of mortality will lead in decline of fertility, decline of population growth, increase of the proportion of working age and then increase of per capita income.

Empirical studies confirm that lower health status results in lower working hours (Cai et al., 2008) or lower labor force participation (Zhang et al., 2009; Garcia-Gomez et al., 2010). Previous studies also show that good health status has a positive correlation with income and vice versa illness has a negative influence on income (Liu et al., 2008; Schofield et al., 2011). Further, illness along with related medical expenditure reduces individual's or household consumption that would affect individual's welfare (Gertler \& Gruber, 2002; Wang et al., 2006; Wagstaff, 2007)

On the other hand, not all determinants of individual's welfare are reflected in market price. Therefore, economists should appreciate the subjective well-being as an option to analyse individual welfare (Ott, 2008). Subjective well-being is a measurement that can complement other measurements of welfare and help to understand the drivers of individual's well-being (OECD, 2013). Subjective well-being is people's emotional and cognitive evaluation of their lives (Diener et al., 1999). The evaluation includes positive and negative effects and the satisfaction of individual's life either in general or in a specific domain of life. In many occasion, the term subjective well-being is often used interchangeably with the term happiness or a life satisfaction. The most applicable method to measure the subjective well-being is conducting survey by requiring respondents to give answers in what level they feel happy (Easterlin, 1974; Frey et al., 2002). As an example, United States General Social Survey uses a question "Taken all together, how would you say things are these days: would you say that you are very happy, pretty happy or not too happy?" to measure respondent's happiness perception. Although 
this measurement is subjective, in the context of democracy life, people's opinion to their life evaluation should be respected and noticed by policy maker as a part of the assessment of their life success (Diener, 2000).

Empirical researches indicate the existence of positive influence of health on subjective well-being (Oswald et al., 2006; Mukuria et al., 2012; Bockerman et al., 2011; Sohn, 2014; Wang et al., 2000; Rahayu, 2016). Individuals with a better health status have a higher level of happiness. To measure the level of happiness, previous research use different scale of self-reported subjective well-being such as 3 scale (Sohn, 2014; Rahayu, 2016), 4 scale (Wang et al., 2015); 5 scale (Mukuria et al., 2013), 7 scale (Oswald et al., 2006) and 10 scale (Bockerman et al., 2011). Previous studies also use various health measures such as anthropometric indicators, diagnosed disease or chronic condition and subjective health status. For example, Sohn (2014) found that tall men and women are happier than their short counterparts. Meanwhile, Bockerman et al. (2011) found that an individual who has chronic condition such as disorder of lung function, heart, muscles, hearing, sight, neurosis and psychiatric problem has lower happiness level. Rahayu (2016) reported that individuals with higher perceived general health status have greater happiness. Meanwhile, by using multidimensional instrument such as EuroQol-5 Dimension (EQ-5D) and Short Form-5 Dimension (SF-5D), researchers can examine deeper the influence of each dimension. Using the EQ-5D and SF-5D instrument, Mukuria et al. (2012) found that mental health (depression and anxiety), vitality and social functioning were found have a large significant association with the patients's own happiness assessment. Among five components of EQ-5D instrument, Wang et al. (2015) also found that depression has a negative impact to the subjective well-being.

Although numerous researches have been conducted to explain the effect of health on the subjective well-being, studies that looked at functional limitation measures are lacking, especially for the case in developing countries such as Indonesia. The study about functional limitation is relevant to conduct in Indonesia for some reasons. One of reasons is aging population. Along with the increase in the age of life expectancy, the Central Bureau of Statistics of Indonesia forecasts an increase of the aging population in the composition of the entire Indonesian population by the year 2035 (Adioetomo \& Mujahid, 2014b). One of the main issues on the aging population is the declining of physical ability that could impact individual's quality of life. Based on survey data, majority of the elderly of Indonesian population continue to work for pay, especially on poor household (Adioetomo et al., 2014a). A decline in physical ability will limit elderly in economic and social or cultural activities. As explained before, this limitation on economic activity will affect the individual's well-being. Therefore, this study tries to answer the question on the relationship between functional limitation and individual's subjective well-being in Indonesia. Functional limitations are assessed in three domains that are physical functions, basic Activity of Daily Livings (ADLs), and Instrumental Activity of Daily Livings (IADLs). In this study we focus on physical function as our interest variable of health status.

Physical function measurement is an important cause of numerous aspects of individual's socioeconomic status (Fonda, 2004). Fox et al. (2007) and Garatachea et al. (2008) conducted a quasi-experimental research and found that physical function and physical activity has a relationship with feelings of well-being. Different subjective well-being is used in those research, Fox use the Satisfaction with Life Scale, which is a self-administered questionnaire with five non-specific items on a seven point scale, to assess global life satisfaction. Meanwhile, Garatachea use 30 items measure of happiness sense. Although weak, Fox et al. (2007) found that total daily physical activity energy expended (joules/day) and amount of time spent on physical activity is correlated with subjective well-being. Individual who are active in physical activities have higher level of subjective well-being than individual who are less active (Garatachea et al., 2008). However, by using small sample, previous studies were difficult to yield a robust result if the samples were grouped and analyzed based on demographics background such as the language spoken (Fox et al., 2007). In our study, we use large data that represent characteristics of Indonesia's population. Since social relationship, education, religion and basic needs have significant impacts on the subjective well-being especially for individuals in eastern countries (Jaafar et al., 2012), we use socioeconomic and demographic data as control variables in our regression model that are not included in the research of Fox and Garatachea.

Besides that, the previous empirical studies did not consider an endogeneity problem that may results in bias estimates. Diener at al. (2011) and Sabatini (2014) argued that happiness is a good predictor of health status. People who have a higher level of happiness will restrict themselves from behaviour that can reduce the level of health. Furthermore, based on the disability model proposed by Verbrugge and Jette (1994), disability is affected by factors such as impairment that may unobservable. This possibility of a reversed causality and unobserved variables may lead into an endogeneity problem. We use an ordered logit model approach with the instrumental variable (IV) to correct for this endogeneity problem. In this study, we use the number of fallen down as an instrumental variable for the physical function index. We estimate this IV-Ordered Logit regression using a Two 
Stage Residual Inclusion (2SRI) method.

After controlling for socioeconomic and demographic factors, we found that the physical function index has a positive significant impact on the subjective well-being. Based on the marginal effect results, on average, increasing on one unit of the physical function index will increase the probability of being very happy about $1.5 \%$. Since the magnitude of the coefficient in the IV-Ordered Logit is larger than that in the ordinary Ordered Logit, we conclude that there is no existence of a reversed causality. Therefore, a physical function is a good predictor for the subjective well-being.

Numerous literatures have demonstrated that health is related to subjective well-being. To the best of our knowledge, this present work is the first study that examines a physical function as a determinant of subjective well-being. By focusing on the physical function, our finding advances previous findings that health is strongly related to subjective well-being. Our study use large survey data that represents population characters. Our findings support previous quasi experimental researches (Fox et al., 2007; Garatachea et al., 2008) that conclude that being able to do various activities make an individual happier. On the aspect of methodology, we offer the novel approach by using IV-Ordered Logit model for this case.

The rest of the paper is organized as follows. First, we present our data source and empirical strategies. In this section we also present an overview about IV-Ordered Logit method. Second, we present the summary of descriptive statistic, first stage regression and second stage regression results. The discussion based on regression results is presented in the third section. We also compare the result of IV-Ordered Logit regression with ordinary Ordered Logit model. Finally, we conclude our finding by considering limitations of our research.

\section{Data and Method}

\subsection{Data}

This research uses the most current dataset of Indonesian Family Life Survey (IFLS) data wave 5, year 2014. The IFLS is a national scale survey that provides a rich dataset at three levels (individual, household and communities). The survey is a representation of more than 80 percent of Indonesian population. The observation used in this research is individual level. We use information on individual's health condition, education, socio-economic and demographic characters of the individuals, and social capital.

\subsection{Empirical Strategy}

The outcome variable of this research is a subjective well-being that derived from the survey question "Taken all things together how would you say things are these days, would you say you were very happy, happy, unhappy or very unhappy?" The original responses for this question are 1 (very happy), 2 (happy), 3 (unhappy) and 4 (very unhappy). Then, these responses are reversed, so a higher score reflects a greater happiness.

Physical functions' measurement in the IFLS survey is adapted from the United States Health and Retirement Study and is modified to fit into the local context (Sujarwoto, 2015). There are eleven questions about the physical function in IFLS wave 5. The questions are about the respondent's ability of doing some activities such as "to carry a heavy load", "to walk for 1 kilometer", "to walk across the room" and "to reach or extend arms above shoulder level". The original responses for each question are 1 (easily), 3 (with difficulty) and 5 (unable to do it). For further analysis, these responses are reversed and then are summed for each respondent. The score is indexed with following algorithm (Hays et al., 1995; Fayers et al., 2000):

$$
\text { Physical Function Index }=(\text { Score }- \text { Min.Score }) /(\text { Max.Skor }- \text { Min.Skor }) \times 100
$$

If the individual can easily perform all activities, the index value will be 100 and if the individual is unable to perform all activities, the index value will be 0 (zero).

Since the subjective well-being is the ordinal value, we use ordered logit model as follow:

$$
S W B_{i}^{*}=\beta_{1} H_{i}+\sum_{k} \beta_{k} Z_{i k}+\varepsilon_{i}
$$

where $S W B_{i}{ }^{*}$ is a latent variable of the subjective well-being of an individu $i, H_{i}$ is the physical function index of an individual $i$ and $Z_{i k}$ is a vector of control variable $k$ of an individual $i, \varepsilon_{i}$ indicates the error term, $\beta_{1}$ and $\beta_{2}$ are coefficients to be estimated. The connection between the latent variable $S W B_{i}{ }^{*}$ and the observed response category is:

$$
S W B=\left[\begin{array}{c}
=1 \text { if } S W B^{*} \leq \alpha_{1} \\
=2 \text { if } \alpha_{1}<S W B^{*} \leq \alpha_{2} \\
=3 \text { if } \alpha_{2}<S W B^{*} \leq \alpha_{3} \\
=4 \text { if } \alpha_{3}<S W B^{*}
\end{array}\right]
$$


where $\alpha 1, \alpha 2, \alpha 3$ and $\alpha 4$ are unknown cut points and are estimated, along with $\beta_{1}$ and $\beta_{2}$.

The control variables used in this research are consisting of foods expenditure, education, social capital and demographic variables of individuals. We use food expenditure as a proxy of an income indicator. The increase in individual's income is not always followed by the increase of the subjective well-being (Easterlin, 2002). Nevertheless, empirical researches in developing countries indicate the positive effect of the income on the subjective well-being (Diener et al., 2001; Rahayu et al., 2016).

Social capital has a significant influence on the subjective well-being especially for individuals in eastern countries (Jaafar et al., 2012). Therefore, we use four variables as proxies of the social capital. Those social capital variables are derived from questions about religiosity, a willingness to help neighbours, how safe the village where the individual lives and the acceptance over individuals with different faiths.

Since previous studies showed the U-shaped relationship between the age and the subjective well-being, we use the age and its squared value in the model specification. We also add a dummy variable for a marital status (married or unmarried), sex (male or female), a working status (working or not working), a region (urban or rural), and whether the individual lives in Java or outside Java island to represents the differences in the economic development of the region.

\subsection{Endogeneity Issue}

Sabatini (2014) estimated that happiness is a good predictor of health. People who have a better happiness will restrict themselves from behaviour that can reduce the level of health. Based on those findings, there is a possibility of a reverse causality between happiness and health status. Therefore, we threat the physical index as an endogenous variable and use an instrumental variable approach to correct this endogeneity problem.

A valid instrument must be correlated with the endogenous explanatory variable, but must be uncorrelated with the outcome variable. Based on the disability process model of Verbrugee and Jette (1994), the physical function is influenced by a pathology disorder and a physical impairment. Impairments are disfunctions and significant structural abnormalities in a specific body system. Individual who experienced accident or fallen down probably get some physical impairments. In this study, the physical function index is instrumented with the number of fallen down in the last two years. This data is derived from the survey question "how many times have you fallen down in the last two years?"

To implement an ordered logit model with an instrumental variable, we follow the two-stage residual inclusion (2SRI) model (Terza, 2008; Wooldridge, 2010). In the first stage, the physical function index is regressed on the instrument (the number of individual's has fallen down) and all exogenous regressors. Then, the residuals from the first-stage regression were incorporated into an ordered logit regression of the subjective well-being on the covariate vector, the physical index, and the residuals. Followings are procedure of 2SRI.

$$
S W B_{1}^{*}=\gamma_{2} H_{2}+\delta_{1} Z_{1}+u_{1}
$$

where $H_{2}$ is the physical function index which is endogenous and $Z_{l}$ is all exogenous variables. We first regress the physical function index on all exogenous variables and the instrument variable as follow:

$$
H_{2}=\boldsymbol{Z} \delta_{2}+v_{2}
$$

if we write $u_{1}=\theta_{1} v_{2}+e_{l}$ and plug into the equation (4), we obtain

$$
S W B_{1}^{*}=\gamma_{2} H_{2}+\delta_{1} Z_{1}+\theta_{1} v_{2}+e_{1}
$$

The endogeneity exist if the residual value of the equation $5\left(v_{2}\right)$ and the residual value of the equation $4\left(u_{1}\right)$ are correlated. A simple test of the null hypothesis that $H_{2}$ is exogenous is by analyzing whether the coefficient of the first stage residual value, $\theta_{1}$, is significant or not. If $\theta_{1}$ is significant, then the null hypothesis that $H_{2}$ is exogenous can be rejected (Wooldridge, 2010).

\section{Result}

\subsection{Descriptive Statistics}

This study has 31,217 observations. Table 1 informs that there are 73 percent of married, 47 percent of male, 59 percent of individuals live in urban and 54 percent of that live in Java Island. There is 91.49 percent of individuals who feel happy and very happy. Meanwhile, individuals who feel unhappy and very unhappy is only about 8.51 percent of total. On average, individuals who perceived higher level of happiness have higher physical function index as shown on Table 3. These data supports our hypothesis that there is a connection between health status and the subjective well-being. 
Table 1. Summary of Descriptive Statistics

\begin{tabular}{cccc}
\hline Variable & Number of observation & Mean & Standard Deviation \\
\hline Subjective well-being & 31217 & 3.04 & 0.5 \\
Married & 31217 & $73 \%$ & $45 \%$ \\
Male & 31217 & $47 \%$ & $5 \%$ \\
Age (Year) & 31217 & 37.24 & 14.95 \\
Live in urban & 31217 & $59 \%$ & $49 \%$ \\
Live in Java Island & 31217 & $54 \%$ & $5 \%$ \\
Willingness to help neighbor & 31217 & 3.25 & 0.46 \\
Safety level of the village & 31217 & 3.15 & 0.51 \\
Religiosity & 31217 & 2.9 & 0.68 \\
Acceptance over individuals with different faith. & 31217 & 2.76 & 0.61 \\
Education (Year) & 31217 & 9.72 & 3.84 \\
Food Consumption (Rupiah) & 31217 & $403,953.50$ & $319,010.80$ \\
Household Members (person) & 31217 & 6.31 & 3.36 \\
Working & 31217 & $59 \%$ & $49 \%$ \\
\hline
\end{tabular}

Note: Values are in index numbers, except that it is stated in the table; Source: IFLS 2014, author's calculation

Table 2. Distribution of Subjective Well-Being

\begin{tabular}{ccc}
\hline Subjective well-being & Number of Observation & Percentage \\
\hline Very Unhappy & 332 & 1.06 \\
Unhappy & 2,325 & 7.45 \\
Happy & 24,427 & 78.25 \\
Very Happy & 4,133 & 13.24 \\
\hline Total & 31,217 & 100 \\
\hline
\end{tabular}

Source: IFLS 2014, author's calculation

Table 3. Average of Physical Function Index by Subjective Well-Being Status

\begin{tabular}{cc}
\hline Subjective well-being & Physical Function Index (Average) \\
\hline Very Unhappy & 90.279 \\
Unhappy & 90.461 \\
Happy & 94.068 \\
Very Happy & 94.271 \\
\hline
\end{tabular}

Source: IFLS 2014, author's calculation

\subsection{IV-Ordered Logit Regression Result}

The test of the instrument shows that the instrument, the number of fallen down, has a significant impact on the physical function index at $1 \%$ significant level. Meanwhile, this instrument is not statistically significant influence the outcome variable, the subjective well-being. Therefore, it can be concluded that the number of fallen down is a valid instrument for the physical function index.

Table 4 shows the results of the first stage regression. The instrument variable, the number of fallen down, has a significant effect on the physical function index. The negative sign on the coefficients shows that the higher the number of fallen down will reduce the physical function index. As explained in the previous section, the physical impairment is one of the causes of the declining of the physical function ability. Other variables that are statistically significant influence the physical function are male, age and its squared term, an individual who is living in Java island, religiosity, tolerance, years of education, the number of household members, and an employed individual.

In the second stage regression, the residual value of the first stage is included in the regression model. Table 5 shows the second stage regression result. The coefficient of the first stage residual value is statistically significant. Thus, the null hypothesis that the physical function index is exogenous can be rejected. 
The result of the second regression indicates that the physical function index has a significant effect on the subjective well-being. The positive sign means that the higher the physical index, the higher the subjective well-being level. Based on these findings, it can be concluded that the health status has a positive significant effect on the subjective well-being.

Table 4. First Stage Regression Result

\begin{tabular}{ccccc}
\hline Dependent Variable: Physical Function Index & Coefficient & Standard Error & $\mathrm{t}$ & $\mathrm{P}>\mathrm{t}$ \\
\hline Number of Fallen Down & -0.183 & 0.027 & -6.790 & $0.000^{* * *}$ \\
Married & -0.195 & 0.121 & -1.610 & 0.107 \\
Male & 3.117 & 0.098 & 31.940 & $0.000^{* * *}$ \\
Age & 0.376 & 0.018 & 21.470 & $0.000^{* * *}$ \\
Age Squared & -0.006 & 0.000 & -29.310 & $0.000^{* * *}$ \\
Live in urban & -0.060 & 0.096 & -0.620 & 0.532 \\
Live in Java Island & 1.426 & 0.091 & 15.660 & $0.000^{* * *}$ \\
Willingness to help neighbor & -0.054 & 0.098 & -0.550 & 0.583 \\
Safety level of the village & 0.090 & 0.088 & 1.030 & 0.305 \\
Religiosity & 0.201 & 0.067 & 3.000 & $0.003 * * *$ \\
Acceptance over individuals with different faith. & 0.251 & 0.074 & 3.400 & $0.001 * * *$ \\
Log. Natural Food Consumption & 0.067 & 0.061 & 1.090 & 0.275 \\
Education & 0.156 & 0.014 & 11.580 & $0.000^{* * *}$ \\
Household Members & -0.076 & 0.014 & -5.580 & $0.000^{* * *}$ \\
Working & 1.205 & 0.103 & 11.720 & $0.000^{* * *}$ \\
Constant & 83.209 & 0.897 & 92.730 & 0.000 \\
\hline
\end{tabular}

*** is significant at 1 percent level; Source: IFLS 2014, author's calculation

Table 5. Second Stage Regression Result

\begin{tabular}{|c|c|c|c|c|}
\hline Dependent Variable: Subjective Well-Being & coeff. & Std. Err. & Z & $\mathrm{P}>\mathrm{Z}$ \\
\hline Physical Function Index & 0.141 & 0.047 & 3.000 & $0.003 * * *$ \\
\hline Married & 0.781 & 0.038 & 20.320 & $0.000 * * *$ \\
\hline Male & -0.579 & 0.149 & -3.900 & $0.000 * * *$ \\
\hline Age & -0.138 & 0.019 & -7.270 & $0.000 * * *$ \\
\hline Age Squared & 0.002 & 0.000 & 5.360 & $0.000 * * *$ \\
\hline Live in urban & 0.137 & 0.030 & 4.550 & $0.000 * * *$ \\
\hline Live in Java Island & -0.262 & 0.073 & -3.570 & $0.000 * * *$ \\
\hline Willingness to help neighbor & 0.361 & 0.031 & 11.650 & $0.000 * * *$ \\
\hline Safety level of the village & 0.416 & 0.028 & 14.760 & $0.000 * * *$ \\
\hline Religiosity & 0.341 & 0.023 & 14.570 & $0.000 * * *$ \\
\hline Acceptance over individuals with different faith. & -0.045 & 0.026 & -1.750 & $0.081 *$ \\
\hline Log. Natural Food Consumption & 0.213 & 0.019 & 10.980 & $0.000 * * *$ \\
\hline Education & 0.044 & 0.009 & 5.190 & $0.000 * * *$ \\
\hline Household Members & -0.002 & 0.006 & -0.430 & 0.667 \\
\hline Working & -0.049 & 0.066 & -0.750 & 0.453 \\
\hline residual $1^{\text {st }}$ Stage & -0.126 & 0.047 & -2.660 & $0.000 * * *$ \\
\hline /cut1 & 12.438 & 3.932 & & \\
\hline /cut2 & 14.661 & 3.932 & & \\
\hline /cut3 & 19.309 & 3.933 & & \\
\hline
\end{tabular}

*** is significant at 1 percent level, ** at 5 percent level, $*$ at 10 percent level

Source: IFLS 2014, author's calculation

Socio-economic variables such as household consumption and years of education are also statistically significant influence the subjective well-being and have the expected signs. It means that an increase in the household consumption improves the subjective well-being. Individuals with higher education are happier. Besides that, the 
social capital variables which are the willingness to help neighbors and the trust, are also give positive significant impacts on the subjective well-being. Better social capital is happier.

The demographic characteristics also have significant influences on the subjective well-being. Female, married one, living in urban area and living outside Java island are happier than male, unmarried, living in rural area, and living in Java island. However, the number of household members and working status are not statistically significant in affecting the subjective well-being.

Since the model is the ordered logit regression model, therefore we cannot interpret the coefficients of estimated. The appropriate analysis for this nonlinear model is using the marginal effect. The marginal effect measures the impact of one unit change in a predictor at one unit of a probability of each level of the subjective well-being. Table 6 shows the result of the marginal effects. In this study, we use Average Marginal Effect model.

On average, one unit change in the physical function index, the probability to be very happy $(\mathrm{SWB}=4)$ is increased by 1.5 percent. Meanwhile, the change of the physical function index by one unit causes a decrease in the probability of felling happy $(\mathrm{SWB}=3$ ) by 0.5 percent. Besides that, the increase of the physical function index by one unit causes the probability of being unhappy $(\mathrm{SWB}=2)$ is reduced by 0.9 percent. Moreover, the increase of the physical function index by one unit will decrease of felling very unhappy $(\mathrm{SWB}=1)$ by 0.1 percent. It can be concluded that the increasing of the physical function tends to influence individuals of having very happy condition.

Table 6. Average Marginal Effect

\begin{tabular}{|c|c|c|c|c|}
\hline Dependent Variabel: Subjective Well-Being & $\begin{array}{l}\text { Very Unhappy } \\
(\mathrm{SWB}=1)\end{array}$ & $\begin{array}{l}\text { Unhappy } \\
(\mathrm{SWB}=2)\end{array}$ & $\begin{array}{c}\text { Happy } \\
(\mathrm{SWB}=3)\end{array}$ & $\begin{array}{c}\text { Very Happy } \\
(\mathrm{SWB}=4)\end{array}$ \\
\hline Physical Function Index & $-0.001 * * *$ & $-0.009 * * *$ & $-0.005 * * *$ & $0.015^{* * *}$ \\
\hline Married & $-0.010 * * *$ & $-0.057 *$ & $-0.009 * * *$ & $0.076^{*}$ \\
\hline Male & $0.006 * * *$ & $0.037 * *$ & $0.019 * *$ & $-0.063 *$ \\
\hline Age & $0.001 * * *$ & $0.009 * * *$ & $0.005 * * *$ & $-0.015 * *$ \\
\hline Age Squared & $0.000 * * *$ & $0.000 * * *$ & $0.000 * * *$ & $0.000 * * *$ \\
\hline Live in urban & $-0.001 * * *$ & $-0.009 * * *$ & $-0.005 * * *$ & $0.015 * *$ \\
\hline Live in Java Island & $0.003 * * *$ & $0.016^{* *}$ & $0.010 * * *$ & $-0.029 * *$ \\
\hline Willingness to help neighbor & $-0.004 * * *$ & $-0.023 * *$ & $-0.013 * *$ & $0.039 * *$ \\
\hline Safety level of the village & $-0.004 * * *$ & $-0.027 * *$ & $-0.015 * *$ & $0.046^{* *}$ \\
\hline Religiosity & $-0.004 * * *$ & $-0.022 * *$ & $-0.012 * *$ & $0.037 * *$ \\
\hline Acceptance over individuals with different faith. & $0.000 * * *$ & $0.003 * * *$ & $0.002 * * *$ & $-0.005 * * *$ \\
\hline Log. Natural Food Consumption & $-0.002 * * *$ & $-0.013 * *$ & $-0.008 * * *$ & $0.023 * *$ \\
\hline Education & $0.000 * * *$ & $-0.003 * * *$ & $-0.002 * * *$ & $0.005 * * *$ \\
\hline Household Members & $0.000 * * *$ & $0.000 * * *$ & $0.000 * * *$ & $0.000 * * *$ \\
\hline Working & $0.001 * * *$ & $0.003 * * *$ & $0.002 * * *$ & $-0.005 * * *$ \\
\hline
\end{tabular}

*** is significant at 1 percent level, ** at 5 percent level, * at 10 percent level; Source: IFLS 2014, author's calculation

\subsection{Robustness Check}

Robustness of the predictors could be seen from the consistency of its sign and its significance as shown in Table 7. We add a depression as an explanatory variable on the regression model. We also use interaction terms as additional variables included in the model. As shown in table 7, the interaction between the physical function index and the logarithm of food consumption is used in the model 3 and the interaction between the physical function index and education is used in the model 4. In Table 8, we compare the result of IV-Orderd Logit to the ordinary ordered logit model. The signs and the significances of the coefficients of estimated are not changes in the model 3 and 4, therefore, we can conclude that the IV-Ordered Logit Model in Model 1 of Table 7 is robust. 
Table 7. Regression Result of Several Model of IV-Ordered Logit

\begin{tabular}{|c|c|c|c|c|c|c|c|c|}
\hline \multirow{2}{*}{$\begin{array}{l}\text { Dependent Variabel: } \\
\text { Subjective Well-Being }\end{array}$} & \multicolumn{2}{|c|}{ Model 1} & \multicolumn{2}{|c|}{ Model 2} & \multicolumn{2}{|c|}{ Model 3} & \multicolumn{2}{|c|}{ Model 4} \\
\hline & Coef. & $\mathrm{P}>\mathrm{Z}$ & Coef. & $\mathrm{P}>\mathrm{Z}$ & Coef. & $\mathrm{P}>\mathrm{Z}$ & Coef. & $\mathrm{P}>\mathrm{Z}$ \\
\hline Physical Function Index & 0.141 & $0.003 * * *$ & 0.112 & $0.035^{* *}$ & 0.127 & $0.014 * *$ & 0.143 & $0.002 * * *$ \\
\hline Depression & & & -0.263 & $0.000 * * *$ & & & & \\
\hline $\begin{array}{l}\text { Physical Function x Log. } \\
\text { Food Consumption }\end{array}$ & & & & & 0.001 & 0.503 & & \\
\hline $\begin{array}{l}\text { Physical Function } \mathrm{x} \\
\text { Education }\end{array}$ & & & & & & & 0.000 & 0.604 \\
\hline Married & 0.781 & $0.000 * * *$ & 0.764 & $0.000 * * *$ & 0.781 & $0.000 * * *$ & 0.780 & $0.000 * * *$ \\
\hline Male & -0.579 & $0.000 * * *$ & -0.488 & $0.003 * * *$ & -0.580 & $0.000 * * *$ & -0.580 & $0.000 * * *$ \\
\hline Age & -0.138 & $0.000 * * *$ & -0.129 & $0.000 * * *$ & -0.138 & $0.000 * * *$ & -0.138 & $0.000 * * *$ \\
\hline Age Squared & 0.002 & $0.000 * * *$ & 0.001 & $0.000 * * *$ & 0.002 & $0.000 * * *$ & 0.002 & $0.000 * * *$ \\
\hline Live in urban & 0.137 & $0.000 * * *$ & 0.147 & $0.000 * * *$ & 0.137 & $0.000 * * *$ & 0.137 & $0.000 * * *$ \\
\hline Live in Java Island & -0.262 & $0.000 * * *$ & -0.226 & $0.005 * * *$ & -0.262 & $0.000 * * *$ & -0.262 & $0.000 * * *$ \\
\hline $\begin{array}{l}\text { Willingness to help } \\
\text { neighbor }\end{array}$ & 0.361 & $0.000 * * *$ & 0.371 & $0.000 * * *$ & 0.360 & $0.000 * * *$ & 0.361 & $0.000 * * *$ \\
\hline Safety level of the village & 0.416 & $0.000 * * *$ & 0.408 & $0.000 * * *$ & 0.416 & $0.000 * * *$ & 0.416 & $0.000 * * *$ \\
\hline Religiosity & 0.341 & $0.000 * * *$ & 0.342 & $0.000 * * *$ & 0.341 & $0.000 * * *$ & 0.341 & $0.000 * * *$ \\
\hline $\begin{array}{l}\text { Acceptance over } \\
\text { individuals with different } \\
\text { faith. }\end{array}$ & -0.045 & $0.081^{*}$ & -0.053 & $0.035 * *$ & -0.046 & $0.080^{*}$ & -0.045 & $0.082 *$ \\
\hline $\begin{array}{l}\text { Log. Natural Food } \\
\text { Consumption }\end{array}$ & 0.213 & $0.000 * * *$ & 0.214 & $0.000 * * *$ & 0.109 & 0.483 & 0.213 & $0.000 * * *$ \\
\hline Education & 0.044 & $0.000 * * *$ & 0.049 & $0.000 * * *$ & 0.044 & $0.000 * * *$ & 0.062 & $0.076^{*}$ \\
\hline Household Members & -0.002 & 0.667 & -0.004 & 0.505 & -0.002 & 0.676 & -0.002 & 0.660 \\
\hline Working & -0.049 & 0.453 & -0.002 & 0.974 & -0.049 & 0.452 & -0.049 & 0.451 \\
\hline residual $1^{\text {st }}$ Stage & -0.126 & $0.008 * * *$ & -0.100 & $0.059 *$ & -0.126 & $0.008 * * *$ & -0.126 & $0.008 * * *$ \\
\hline
\end{tabular}

$* * *$ is significant at 1 percent level, ** at 5 percent level, * at 10 percent level; Source: IFLS 2014, author's calculation

Table 8. Comparison between IV-Ordered Logit and Ordinary Ordered Logit

\begin{tabular}{|c|c|c|c|c|}
\hline \multirow{2}{*}{ Dependent Variabel: Subjective Well-Being } & \multicolumn{2}{|c|}{ IV-Ordered Logit } & \multicolumn{2}{|c|}{ Ordered Logit } \\
\hline & Coef. & $\mathrm{P}>\mathrm{Z}$ & Coef. & $\mathrm{P}>\mathrm{Z}$ \\
\hline Physical Function Index & 0.141 & $0.003 * * *$ & 0.016 & $0.000 * * *$ \\
\hline \multicolumn{5}{|l|}{ Depression } \\
\hline Married & 0.781 & $0.000 * * *$ & 0.762 & $0.000 * * *$ \\
\hline Male & -0.579 & $0.000 * * *$ & -0.193 & $0.000 * * *$ \\
\hline Age & -0.138 & $0.000 * * *$ & -0.090 & $0.000 * * *$ \\
\hline Age Squared & 0.002 & $0.000 * * *$ & 0.001 & $0.000 * * *$ \\
\hline Live in urban & 0.137 & $0.000 * * *$ & 0.129 & $0.000 * * *$ \\
\hline Live in Java Island & -0.262 & $0.000 * * *$ & -0.082 & $0.004 * * *$ \\
\hline Willingness to help neighbor & 0.361 & $0.000 * * *$ & 0.353 & $0.000 * * *$ \\
\hline Safety level of the village & 0.416 & $0.000 * * *$ & 0.428 & $0.000 * * *$ \\
\hline Religiosity & 0.341 & $0.000 * * *$ & 0.367 & $0.000 * * *$ \\
\hline Acceptance over individuals with different faith. & -0.045 & $0.081 *$ & -0.015 & 0.522 \\
\hline Log. Natural Food Consumption & 0.213 & $0.000 * * *$ & 0.220 & $0.000 * * *$ \\
\hline Education & 0.044 & $0.000 * * *$ & 0.064 & $0.000 * * *$ \\
\hline Household Members & -0.002 & 0.667 & -0.012 & $0.004 * * *$ \\
\hline Working & -0.049 & 0.453 & 0.103 & $0.001 * * *$ \\
\hline residual $1^{\text {st }}$ Stage & -0.126 & $0.008 * * *$ & 0.762 & $0.000 * * *$ \\
\hline
\end{tabular}

*** is significant at 1 percent level, ** at 5 percent level, * at 10 percent level; Source: IFLS 2014, author's calculation 


\section{Discussion}

\subsection{The Impact of Health Status on Subjective Well-Being}

Based on the marginal effect results as shown in Table 6, on average, increasing one unit of the physical function index will increase the probability of being very happy about $1.5 \%$. At the same time, increasing on one unit of the physical function index will decrease the probability of being happy, unhappy and very unhappy. Based on this finding, it is concluded that an increase of one unit of the physical function index leads the individual being very happy. These results are in line with Easterlin (2002) and Oswald et al. (2008) results which state that the disability affects the level of the subjective well-being. Individuals who experience severe disability have lower average levels of the subjective well-being.

Rahayu et al. (2016) and Sohn (2014) use other measurements of health status such as general health status and body mass index.Those health status have positive relationships with the subjective well-being for the case study in Indonesia. Rahayu et al. (2016) stated that healthy people are more productive and earn more income than unhealthy one. Since income is one of indicators of welfare, it means that healthier people is wealthier. Moreover, the findings of our study may also show that a poor health condition or illness is associated with a reduction of the labor supply and the productivity. Gertler and Gruber (2002) found that there are significant economic costs associated with health shocks faced by Indonesian people. The decrease of health condition has an impact on the declining of Indonesian consumption level and next the decreasing in the subjective well-being.

Menec's research (2003) explained that social, productive and solitary activities (hobbies) were related to happiness. Similar result is given by Ruseski et al. (2014). Using Instrumental Variable (IV) approach, Ruseki indicated that individuals who participate in physical activity such as sport caused higher life happiness. Being able to attend these various kinds of activities requires physical effort. Thus, better physical function allows an individual to do activities productively and this lead the individual to be happier. This finding is supported by the comparison between the result of the IV-Orderd Logit and the ordinary ordered logit model as shown in Tabel 8. Both the IV-Ordered Logit and the ordinary ordered logit models have no difference signs on the coefficients of the physical function index. Since the magnitude of the coefficient in the IV-Ordered Logit is larger than that in the ordinary Ordered Logit, we conclude that the physical function is a good predictor for the subjective well-being.

However, after we include depression in our model, the physical function gives less significant influence to the subjective well-being. The depression variable derived from a question whether a respondent feel depressed last week or not. The value will be in range of 1 (rarely or none feel depressed) to 4 (most of time feel depressed). As shown in Table 7 (model 2), depression is negatively correlated with the subjective well-being. After including this additional variable, the physical function index is still positively correlated with the subjective well-being. However, the magnitude and the significance is less than before. Previous studies state that mental health has a higher impact on the subjective well-being than that of the physical health (Wang et al., 2000; Mukuria et al., 2013; Böckerman et al., 2011). Moreover, research of Mukuria found that physical health had no association with happiness while mental health (depression and anxiety) have large significant association with happiness.

Other variables that have significant and positive effects on the subjective well-being are food consumption or expenditure, education and most of the social capital measures. Foods consumption expenditure is used as a proxy for an individual income. This finding supports previous research that income has a strong and positive effect on the subjective well-being, especially in developing countries (Diener et al., 2001; Di Tella, 2003).

Most of the social capital measures are positively correlated with the subjective well-being. Willingness to help neighbor and a safety level of the village have positive effects on the subjective well-being. In contrast to the Western countries, people in the Eastern countries usually live in a society that has a strong social bonding. Thus the quality of a relationship with other members of the society has an impact on happiness (Jaafar et al., 2012). However, the acceptance over individuals with different faith has a negative effect on the subjective well-being. Okulicz-Kozaryn (2010) argued that religion creates a bonding of social capital as opposed to a bridging of social capital.

Furthermore, women have higher level of the subjective well-being than that of men. According to Simmon (2008), women in poorer nations are more satisfied with their incomes than men. This may cause women happier than men. Moreover, married people and individuals who are living in urban area are also happier. Central Bureau of Statistics of Indonesia states that income, ownership of asset, and jobs are the important aspect for happiness (BPS, 2015). Better conditions for the aspects causing the urban people happier from those who live in rural area. Further, the relationship between age and the subjective well-being is like U-shaped curve. It is shown by a negative sign of the age coefficient and a positive sign of the age squared coefficient. Blanchflower and 
Oswald (2008) argue that individuals learn to adapt to their strengths and weaknesses. These adaptations lead individuals able to adjust their happiness level.

\section{Conclusion}

Using Indonesian Family Life Survey 2014 data, we analysis the relationship between health status and the subjective well-being. We use the physical function index as a proxy for health status. After controlling for socioeconomic and demographic factors, we found that the physical function index has a positive impact on the subjective well-being. It can be implied that any intervention that relates to the improvement of health status will improve the individual's well-being. Since the magnitude of the coefficient in the IV-Ordered Logit is larger than that in the ordinary Ordered Logit, there is no existence of a reversed causality. Then, it can be concluded that the physical function is a good predictor for the subjective well-being. The limitation of this study is the use of the cross sectional data. Easterlin (2002) argues that there are individual life cycle effects on the subjective well-being. The lack of data on the panel of the physical function in the IFLS dataset limits the study to observe those effects. Using longitudinal data, the future research hopefully may give possibilities to compare the magnitude of the impact of health status at each stage of the individual life cycle. Further research can explore other physical limitations or disability measures, such as Activity of Daily Livings (ADLs) or Instrumental Activity of Daily Livings (IADLs) that may give more explanations for the individual's subjective well-being.

\section{References}

Adioetomo, S. M., \& Mujahid, G. (2014). UNFPA Indonesia Monograph Series: No.1 Indonesia on the Threshold of Population Ageing. Jakarta: UNFPA.

Adioetomo, S. M., Howell, F., McPherson, A., \& Priebe, J. (2014). Fighting Old-Age Poverty: ASLUT's Role, TNP2K Working Paper 14-2014. Jakarta: TNP2K.

Bircher, J. (2005). Towards a Dynamic Definition of Health and Disease. Medicine, Health Care and Philosophy, 8, 335-341. http://dx.doi.org/10.1007/s11019-005-0538-y

Blanchflower, D. G., \& Oswald, A. J. (2008). Is well-being U-shaped over the life cycle? Social Science \& Medicine, 66(8), 1733-1740. http://dx.doi.org/10.1016/j.socscimed.2008.01.030

Bloom, D. E., \& Canning, D. (2000). The Health and Wealth of Nations. Science, 287(18), 1207-1209 http://dx.doi.org/10.1126/science.287.5456.1207

Bockerman, P., Johansson, E., \& Saarni, S.I. (2011). Do Established Health Related Quality-of-Life Measures Adequately Capture the Impact of Chronic Conditions on Subjective Well-being? Health Policy, 100, 91-95. http://dx.doi.org/10.1016/j.healthpol.2010.10.008

BPS. (2015). Laporan Bulanan Data Sosial Ekonomi (Monthly Report of Social \& Economics Data). Jakarta: BPS

Cai, L., Mavromaras, K., \& Oguzoglu, U. (2008). The Effects of Health and Health Shocks on Hours Worked. Discussion Paper IZA DP No. 3496. Retrieved from http://ftp.iza.org/dp3496.pdf

Cameron, C. A., \& Trivedi, P. K. (2005). Microeconometrics Using Stata. Texas: Stata Press.

Di Tella, R, MacCulloch, R. J., \& Oswald, A. J. (2003). The Macroeconomics of Happiness. Review of Economics and Statistics, 85(4), 809-827. http:// dx.doi.org/10.1162/003465303772815745

Diener, E. (1984). Subjective Well-Being. Psychological Bulletin, 95(3), 542-575. http://dx.doi.org/10.1037/0033-2909.95.3.542

Diener, E. (2000). Subjective Well-Being: The Science Happiness and a Proposal for National Index. American Psychologist, 55, 34-43. . http://dx.doi.org/10.1037/0003-066X.55.1.34

Diener, E., \& Biswas-Diener, R. (2002).Will Money Increase Subjective Well-being? Social Indicators Research, 57(2), 119-169. http://dx.doi.org/10.1023/A:1014411319119

Diener, E., \& Chan, M. Y. (2011). Happy People Live Longer: Subjective Well-Being Contributes to Health and Longevity. Applied Psychology: Health And Well-Being, 3(1), 1-43 http://dx.doi.org/10.1111/j.1758-0854.2010.01045.x

Diener, E., Suh, E. M., Lucas, R. E., \& Smith, H. L. (1999). Subjective Well-Being: Three Decades of Progress. Psychological Bulletin, 125(2), 276-302. Retrieved from https://ssrn.com/abstract=2199216

Easterlin, R. A. (1974). Does Economic Growth Improve the Human Lot? Some Empirical Evidence. In P. A. David \& M. W. Reder (Eds.), Nations and Households in Economic Growth: Essays in Honor of Moses 
Abramowitz (pp 89-125). New $\quad$ York. $\quad$ Academic $\quad$ Press. http://dx.doi.org/10.1016/B978-0-12-205050-3.50008-7

Easterlin, R. A. (2003). Building a Better Theory of Well-Being. Discussion Paper IZA, No 742. Retrieved from https://ssrn.com/abstract=392043

Fayers, P. M., \& Machin, D. (2000). Quality of Life Assement, Analysis and Intepretation. John Wiley \& Sons. http://dx.doi.org/10.1002/sim.941

Fonda, S., \& Herzog, A. R. (2004). Documentation of Physical Functioning Measures in the Health and Retirement Study and the Asset and Health Dynamics among the Oldest Old Study. Survey Research Center University of Michigan Retrieved from http://hrsonline.isr.umich.edu/sitedocs/userg/dr-008.pdf

Fox, K. R., Stathi, A., McKenna, J., \& Davis, M.G. (2007). Physical Activity and Mental Well-Being in Older People Participating in The Better Ageing Project. European Journal of Applied Physiology 100(5), 591$602 \mathrm{http}: / / \mathrm{dx}$.doi.org/10.1007/s00421-007-0392-0

Frey, B. S., \& Stutzer, A. (2000). Maximising Happiness? German Economic Review, 1(2), 145-167 http://dx.doi.org/10.1111/1468-0475.00009

Frey, B. S., \& Stutzer, A. (2002). Economics of Happiness. World Economics, 3(1), 1-17. Retrieved from https://www.bsfrey.ch/articles/_365_2002.pdf

Garatachea, N., Molinero, O., Martınez-Garcia, R., Jimenez-Jimenez, R., Gonzalez-Gallego, J., \& Sara Marquez, S. (2009). Feelings of Well Being in Elderly People: Relationship to Physical Activity and Physical Function. Archives of Gerontology and Geriatrics, 48, 306-312 http://dx.doi.org/10.1016/j.archger.2008.02.010

Garcia-Gomez, P., Jones, A. M., \& Rice, N. (2010). Health Effects on Labour Market Exits And Entries. Labour Economics 17(1), 62-76. http://dx.doi.org/10.1016/j.labeco.2009.04.004

Gertler, P., \& Gruber, J. (2002). Insuring Consumption Against Illness. American Economic Review, 92(1), 51-70. http://dx.doi.org/ 10.1257/000282802760015603

Grossman, M. (1972). On The Concept of Health Capita and the Demand For Health. Journal of Political Economy 80(2), 223-255. http://dx.doi.org/10.1086/259880

Hays, R. D., Sherbourne, C. D., \& Mazel, R. (1995). User's Manual for the Medical Outcomes Study (MOS) Core Measures of Health-Related Quality of Life. Santa Monica: RAND Corporation. Retrieved from https://www.rand.org/content/dam/rand/pubs/monograph_reports/2008/MR162.pdf

Liu, G. G., Dow, W. H., Fu, A. Z., Akin, J., \& Lance, P. (2008). Income Productivity in China: on the Role of Health. Journal of Health Economics 27(1), 27-44. http://dx.doi.org/10.1016/j.jhealeco.2007.05.001

Menec, V. H. (2003). The Relation Between Everyday Activities and Successful Aging: A 6-Year Longitudinal Study. Journal of Gerontology: Social Sciences 58(2), S74-S82. http://dx.doi.org/10.1093/geronb/58.2.S74

Mukuria, C., \& Brazier, J. (2013), Valuing the EQ-5D and the SF-6D Health States Using Subjective Well-being: a Secondary Analysis of Patient Data. Social Science and Medicine, 77, 97-105. http://dx.doi.org/10.1016/j.socscimed.2012.11.012

OECD. (2013). OECD Guidelines on Measuring Subjective Well-being. OECD Publishing. http://dx.doi.org/10.1787/9789264191655-en

Okulicz-Kozaryn, A. (2011). Does Religious Diversity Make Us Unhappy? Mental Health, Religion \& Culture, 14(10), 1063-1076. http://dx.doi.org/10.1080/13674676.2010.550277

Oswald, A., \& Powdthavee, N. (2008).Does Happiness Adapt? a Longitudinal Study of Disability With Implications for Economists and Judges. Public Economics, 92(5), 1061-1077. http://dx.doi.org/10.1016/j.jpubeco.2008.01.002

Ott, J. C. (2010). Happiness, Economics and Public Policy: A Critique. Journal of Happiness Studies, 11(1), 125-130. http://dx.doi.org/ 10.1007/s10902-008-9125-2

Rahayu, T. P. (2016). The Determinants of Happiness in Indonesia. Mediterranean Journal of Social Sciences, 7(2), 393-404. http://dx.doi.org/10.5901/mjss.2016.v7n2p393

Rahayu, T. P., \& Harmadi, S. H. (2016). The Effect of Income, Health, Education, and Social Capital on Happiness in Indonesia. Asian Social Science, 12(7), 75-87. http://dx.doi.org/10.5539/ass.v12n7p75. 
Ruseski, J. E., Humphreys, B. R., Hallman, K., Wicker, R., \& Breuer, C. (2014). Sport Participation and Subjective Well-Being: Instrumental Variable Results From German Survey Data. Journal of Physical Activity and Health, 11, 396-403. http://dx.doi.org/10.1123/jpah.2012-0001

Sabatini, F. (2014). The relationship between happiness and health: Evidence from Italy. Social Science \& Medicine, 114, 178-187. http://dx.doi.org/10.1016/j.socscimed.2014.05.024

Schofield, D. J., Shrestha, R. N., Percival, R. et al. (2011). Economic Impacts of Illness in Older Workers: Quantifying The Impact of Illness on Income, Tax Revenue and Government Spending. BMC Public Health 11, 418. http://dx.doi.org/10.1186/1471-2458-11-418

Simon, R. J. (2008). Who are Happier: Men or Women? Gend. Issues, 25, 141. http://dx.doi.org/10.1007/s12147-008-9056-6

Sohn, K. (2014). Height and Happiness in a Developing Country. Happiness Study, 17, 1-23. http://dx.doi.org/10.1007/s10902-014-9566-8

Sujarwoto \& Tampubolon, G. (2015). Inflammatory Markers and Physical Performance in Middle-Aged and Older People in Indonesia. Age and Ageing, 44(4), 610-645. http:// dx/doi.org/10.1093/ageing/afv052.

Terza, J. V., Basu, A., \& Rathouz, P. J. (2008). Two-Stage Residual Inclusion Estimation: Addressing Endogeneity in Health Econometric Modeling. Health Economic, 27(3), 531-543. http://dx.doi.org/10.1016/j.jhealeco.2007.09.009

Verbrugge \& Jette. (1994). The Disablement Process. Social Science and Medicine, 38(1), 1-44. http://dx.doi.org/10.1016/0277-9536(94)90294-1

Wagstaff, A. (2007). The Economic Consequences of Health Shocks: Evidence from Vietnam. Journal of Health Economics, 26, 82-100 http://dx.doi.org/10.1016/j.jhealeco.2006.07.001

Wang, H., Zhang, L., \& Hsiao, W. (2006). Ill Health and Its Potential Influence on Household Consumptions in Rural China. Health Policy 78(2-3), 167-177 http://dx.doi.org/10.1016/j.healthpol.2005.09.008

Wang, X., Jia X., Zhu, M., \& Chen, J. (2015). Linking Health States to Subjective Well-being: an Empirical Study of 5854 Rural residents in China. Public Health, 129, 655-666. http://dx.doi.org/10.1016/j.puhe.2015.03.014

Wooldridge, J. M. (2010). Econometric Analysis of Cross Section and Data Panel. London: MIT Press

Zhanga, X., Zhaoa, X., \& Harris, A. (2009). Chronic Diseases and Labour Force Participation in Australia. Journal of Health Economics, 28, 91-108. http://dx.doi.org/10.1016/j.jhealeco.2008.08.001

\section{Copyrights}

Copyright for this article is retained by the author(s), with first publication rights granted to the journal.

This is an open-access article distributed under the terms and conditions of the Creative Commons Attribution license (http://creativecommons.org/licenses/by/4.0/). 